\title{
Evaluation of performance rate, some hematological and biochemical parameters in Iranian Afshari breed fattened sheep fed diet containing Gundelia (Gundelia tournefortii L.)
}

\author{
A. Dehghani-Samani ${ }^{1}$, S. Madreseh-Ghahfarokhi ${ }^{2}$ and A. Dehghani-Samani ${ }^{3 *}$ \\ ${ }^{1}$ Faculty of Veterinary Medicine, Shahrekord University, Shahrekord, Iran \\ ${ }^{2}$ Department of Clinical Sciences, Faculty of Veterinary Medicine, Ferdowsi University of Mashhad, Mashhad, Iran \\ ${ }^{3}$ Department of Clinical Sciences, Faculty of Veterinary Medicine, Shahrekord University, Shahrekord, Iran \\ *e-mail: amirds2008@gmail.com
}

(Received April 20, 2018; Accepted July 22, 2018)

\begin{abstract}
The effects of diets containing Gundelia (Gundelia tournefortii L.), which is a wild plant species in middle east countries, on performance rate and health parameters of Iranian afshari breed sheep were studied for the first time. Totally 60 fattened sheep in three groups were studied via receiving different diets and performance rate, hematological and biochemical parameters, which are related to animals' health and also are indicator for diet's efficiency, for each group were evaluated via laboratory methods. The results of current study show that performance rate and/or hematological and biochemical parameters in group which received diet containing Gundelia hay and grain were same as control group which received standard diet, but performance rate in group which received Gundelia hay singly was lower than other groups. Number of white blood cells, differential number of neutrophils and lymphocytes, concentration of plasma proteins and fibrinogen, serum concentration of total protein, cholesterol and lipase had increases in treatment groups versus control group and number of red blood cells, serum concentration of glucose, albumin and blood urea nitrogen had decreases in treatment groups versus control group. Given to low costs and high-performance rate of Gundelia hay plus grain diet, which is related to presence of high amount of carbohydrates and fatty acids in it, this diet can be considered as an efficient diet for fattened sheep but more studies are need. Study on production's quality in animals are receiving Gundelia diet is suggested as a subject for next studies.
\end{abstract}

Keywords: Gundelia tournefortii L., Hematologic parameters, Afshari breed, biochemical parameters, Performance rate Available online at http://www.vetmedmosul.com

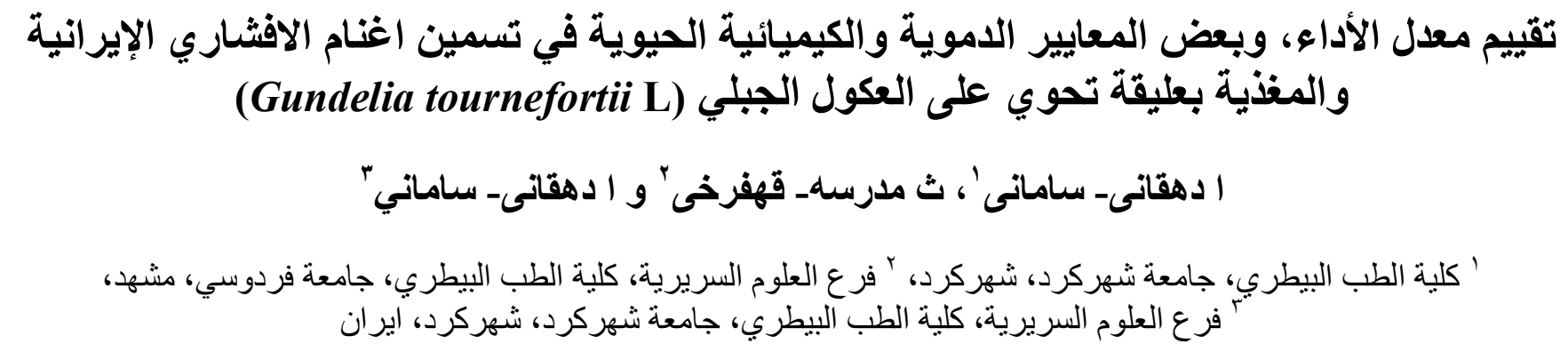

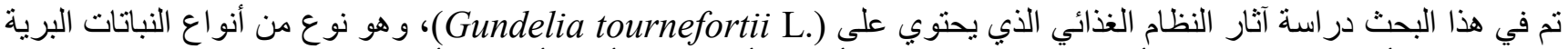

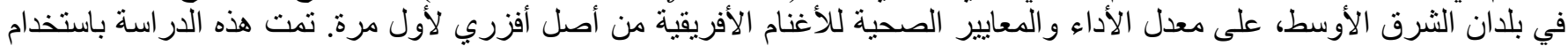

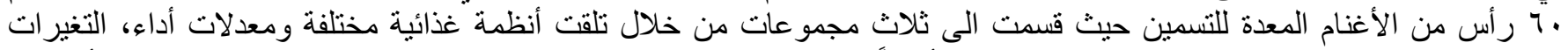

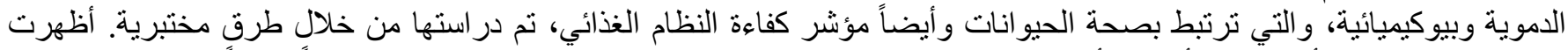

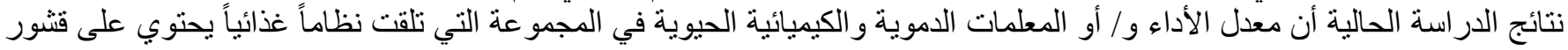




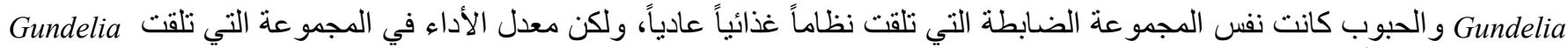

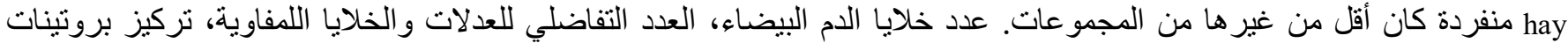

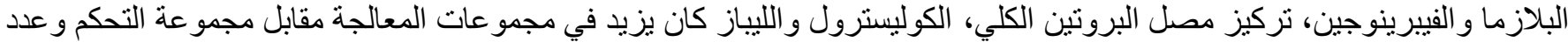

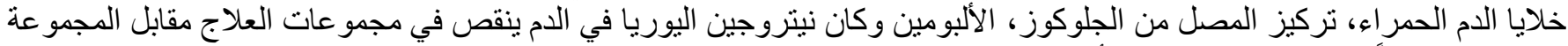

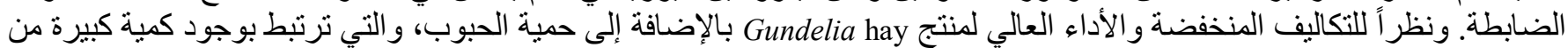

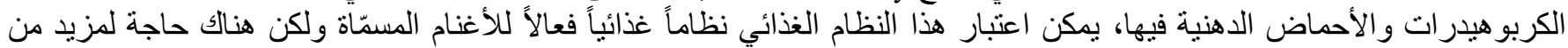

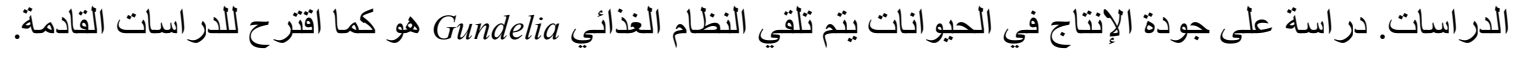

\section{Introduction}

Sheep meat is an important part of family's food schedule in some parts of the world including Iran, so fattened sheep breeders are always trying to find the best breed, which is adapted with their climate and has the highest performance, Iranian afshari sheep breed is a heavy meat-breed, which has high potentials of growth and reproduction and is adapted to Iran's climate. The average of first lambing age, lambing interval and length of mating season are $691.45 \pm 15.45,306.24 \pm 10.16$ and $67.06 \pm 0.235$ days, respectively, the litter size is $1.149 \pm 0.031$ lambs for a year (1). The averages of birth weight, weaning weight and body weight at $6^{\text {th }}$ month of the ages for the lambs of this breed are $3.26 \pm 0.072,22.02 \pm 0.410$ and $31.94 \pm 0.629 \mathrm{~kg}$, respectively. Also, the average daily gain from birth to weaning and weaning to $6^{\text {th }}$ month of the ages are $184.04 \pm 5.02$ and $156.84 \pm 11.81$ gram, respectively (2).

Affordability, availability, efficiency and health security are the most important factors for animals feed sources, which in order to decreasing of costs breeders including fattened sheep breeders, are always seeking for a good diet with the lowest cost for their herds. In this way they are traditionally using from natural resources, which are available and/or free in their location. Gundelia (Gundelia tournefortii L.), which has been identified as one of the well-known and widely distributed plants with various applications in some of Asian and North African countries, belongs to the Asteraceae family and grows in the Middle East particularly in the temperate, mountainous and semi desert areas of countries such as Iran, Iraq, Turkey, Jordan, Syria, Egypt, Turkmenistan and some regions of Azerbaijan and Armenia. This plant is typically known as kangar, tumbleweed, kaoub and kanger in Persian, English, Arabic and Turkish languages, respectively (3).

All parts of this plant are widely used; the young and still undeveloped areal parts, especially flower buds, are sold in the local fairs, the leaves and stems of this plant are used as food ingredients in soups and salads $(4,5)$. Its fruits are treated with vinegar or lemon and salt and used as a garnish (6). The Stem of Gundelia tournefortii L. is used in various parts of Iran as an occasional food with different usages and as a traditional therapy $(7,8)$. In folk medicine, Gundelia tournefortii L. has advantages in the treatment of diseases like bronchitis, vitiligo, chest pain, heart stroke, diabetes, splenomegaly (7-13).

Different parts of this plant after drying and grinding can be used as a complete/partial diet for animals in different regions of the above-mentioned countries, but to the best of authors knowledge and current time effect of diets containing different amounts of Gundelia on performance rate and health status of animals is unidentified. Therefore, the effect of diet containing different amounts of Gundelia tournefortii L. on performance rate, physiological and biochemical parameters in Iranian Afshari breed fattened sheep was studied.

\section{Materials and methods}

\section{Location of study and plant parts}

The current study was conducted in Saman City $\left(32^{\circ} 27^{\prime} 06^{\prime \prime} \mathrm{N} 50^{\circ} 54^{\prime} 38^{\prime \prime} \mathrm{E}\right)$ located in Chaharmahal Va Bakhtiari Province in southwest of Iran. Aerial parts, viz. leaves, stems, flowers and seeds, of Gundelia tournefortii L. plants were collected (from a same field located around the Saman city), dried under sun light, ground immediately and then stored until use in experiments.

\section{Animals and farm condition}

Totally 60 Iranian Afshari breed sheep with the approximately same age (180 \pm 15 days), weight $(25 \pm 5 \mathrm{~kg})$ and sex (male) were studied. Animals were obtained from a same herd and before the experiment they were fed common hays like alfalfa and clover. During the experiment feeding of animals was free and they had free access to water and diet, 24 hours, daily. Temperature (18$25^{\circ} \mathrm{C}$ ), surface area (approximately $20 \mathrm{~m}^{2}$ for each treatment), light (natural daily sun light plus 4-5 hours artificial light and totally about 15 hours daily), humidity (45-55\%), and other environmental factors were the same for groups during the experiment.

\section{Different treatments and performance rate}

In order to assure animal's health, in first step and before the experiment, clinical examinations for all animals were carefully done. Animals were equally divided into three groups containing 20 sheep in each group. During the 
experiment, first group, as control group, received reference diet containing of 1-part oat grain (ground oat grain) and 1part ground alfalfa hay according to Smith (14). Second group, as treatment 1 , received diet containing 1-part oat grain (ground oat grain) and 1 part of ground Gundelia tournefortii $\mathrm{L}$. hay and the third group, as treatment 2, received a diet containing ground Gundelia tournefortii L. hay only, without any grain. In order to calculate the performance rate, animals' initial weights in every group were carefully measured and recorded, also in order to know their initial hematologic and biochemical parameters, 10 animals were randomly selected from each group (totally 30 animals) and hematologic and biochemical parameters were measured. For the digestive system adaptation to new diets, changing of diets to new one was smoothly done during the first seven days (first week). At the end of these 7 days, in order to assure animal's health, clinical examination was repeated again, then the experiment continued for 21 days ( 3 weeks) with new diets for each group. During these days, animals were carefully monitored for any abnormal signs and/or diseases. New meals were added to mangers only when they had eaten their last meals. Animal weights in every group were carefully measured and recorded, at the end of every weeks (totally 4 times plus one time for initial measuring). Finally, after 28 days, all groups were kept off-feed for 8 hours from 12:00 pm till 8:00 am and then blood samples were immediately taken.

\section{Blood samples and hematologic/biochemical parameters}

Before the sampling, bleeding site were carefully cleaned via scrubbing cotton contained ethanol $70 \%$. After evaporation of ethanol, blood samples were collected via puncturing of the external jugular vein by 18 -gauge sterile disposable needle and blood taking tubes. First samples were taken for hematologic parameters using anticoagulant tubes (Green tubes containing heparin) and second samples were taken using plain tubes without any anticoagulant (Red tubes containing no additives). Samples were immediately transferred to the place away from direct sun light and any movements. For second samples, after the formation of clots, sera extracted via centrifuging 2000$3000 \mathrm{rpm}$ for 10 minutes. Sera were kept near the ice packs and sent for laboratory immediately. In laboratory common hematologic parameters including hematocrit, RBC count, WBC count, differential number of neutrophils, lymphocytes, monocytes, eosinophils and Basophils and plasma proteins and fibrinogen were measured via automatic cell counter. Important measurable biochemical parameters of sera including albumin, Blood Urea Nitrogen (BUN), cholesterol, creatinine, glucose, lipase, protein (total), calcium, magnesium, phosphorus, sodium, potassium and Chlorine were also measured via and common specific laboratory methods for metabolic parameters respectively (15). In this investigation hematologic and metabolic reference values, which were released by Oregon State University, were used to compare obtained data with them $(16,17)$.

\section{Statistical analysis}

The data were expressed as the mean \pm standard error of the mean (SEM) using Sigma stat (version 3.1) software. Groups were compared using one-way ANOVA for repeated measurements. Tukey test was used for post hoc analysis. A value of $(\mathrm{P} \leq 0.05)$ was considered significant.

\section{Results}

\section{Performance rate}

The results of the current study (table 1) show that performance rate in the control group was about $4.2 \%$ weekly, and at the end of experiment, animals in this group had about $16 \%$ increase in their body weight. The same results were observed for treatment 1 , which in these groups not only animal had approximately the same results, but also increase of their weights had significantly $(\mathrm{P} \leq 0.05)$ differences versus time, too. Treatment 2 animals had lowest performance rate, and they just experienced about $7 \%$ increase in their weights at the end of experiment. The results indicate that in treatment 2, not only they had lower performance rate than other groups, but also increase of their weight during the last 3 weeks of experiment had not significant differences versus time.

\section{Hematologic parameters}

The results in the table 2 show that the total number of WBC, differential number of neutrophils and lymphocytes, concentrations of plasma proteins and fibrinogen had an increase in treatment groups versus control group and this increase was only significant $(\mathrm{P} \leq 0.05)$ in the treatment 2 , and in this group the increases of total number of $\mathrm{WBC}$, concentrations of plasma proteins and fibrinogen in treatment 2 were also over of reference values. The total number of RBC had a decrease in treatment groups versus control group but this decrease was not significant. Other hematologic parameters had different amount of changes (increasing or decreasing) but their changes were unreliable.

\section{Biochemical parameters}

Table 3 shows that serum concentration of glucose, albumin and blood urea nitrogen had a decrease in treatment groups versus control group, not only this decrease was significant $(\mathrm{P} \leq 0.05)$ in the treatment 2 animals, but also the decrease in serum concentration of glucose and albumin was obviously over of reference values. Serum concentration of total protein, cholesterol and lipase had an increase in treatment groups versus control group, but this increase was significant $(\mathrm{P} \leq 0.05)$ only in the treatment 2 , and the 
increase in serum concentration of total protein in treatment 2 animals was over of reference values. Other biochemical parameters had different amount of changes (increasing or decreasing) but their changes were unreliable.

Table 1: Percentage of weights increases (mean \pm SEM) in different examined groups versus time

\begin{tabular}{lcccc}
\hline Groups & First week & Second week & Third week & Fourth week \\
\hline Treatment 1: (Grain+Gundelia/Alfalfa Hay) & $4.09 \pm 0.65^{\mathrm{A}, \mathrm{a}}$ & $7.99 \pm 0.71^{\mathrm{A}, \mathrm{b}}$ & $11.52 \pm 0.39^{\mathrm{A}, \mathrm{c}}$ & $16.13 \pm 0.52^{\mathrm{A}, \mathrm{d}}$ \\
Treatment 2: (Grain+Gundelia Hay) & $3.97 \pm 0.54^{\mathrm{A}, \mathrm{a}}$ & $6.15 \pm 0.89^{\mathrm{B}, \mathrm{b}}$ & $6.64 \pm 1.03^{\mathrm{B}, \mathrm{b}}$ & $7.06 \pm 1.21^{\mathrm{B}, \mathrm{b}}$ \\
Control group: (Grain+Alfalfa Hay) & $4.26 \pm 0.71^{\mathrm{A}, \mathrm{a}}$ & $8.13 \pm 0.58^{\mathrm{A}, \mathrm{b}}$ & $11.83 \pm 0.72^{\mathrm{A}, \mathrm{c}}$ & $16.47 \pm 0.46^{\mathrm{A}, \mathrm{d}}$ \\
\hline
\end{tabular}

Presence of different superscript uppercase letter $\left({ }^{A-C}\right)$ shows significant differences $(\mathrm{P} \leq 0.05)$ between different treatment groups (rows) in every column (time), and presence of different superscript lowercase letters $\left({ }^{\mathrm{a}-\mathrm{d}}\right)$ shows significant differences $(\mathrm{P} \leq 0.05)$ between different times (column) in every row (treatment groups).

Table 2: Hematologic parameters and their reference values according to Oregon State University (2018a)

\begin{tabular}{lccccc}
\hline Parameters & $\begin{array}{c}\text { Initial } \\
\text { measurement }\end{array}$ & $\begin{array}{c}\text { Treatment } 1 \\
\text { (Grain }+ \text { Gundelia } \\
\text { Hay) }\end{array}$ & $\begin{array}{c}\text { Treatment } 2 \\
\text { Gundelia } \text { Hay) }\end{array}$ & $\begin{array}{c}\text { Control Group } \\
\text { (Grain }+ \text { Alfalfa } \\
\text { Hay) }\end{array}$ & $\begin{array}{c}\text { Reference } \\
\text { Value* }\end{array}$ \\
\hline Hematocrit $(\mathrm{n} \%)$ & $33.52 \pm 2.16^{*}$ & $35.76 \pm 1.61^{*}$ & $34.99 \pm 2.08^{*}$ & $34.41 \pm 0.85^{*}$ & $27-45$ \\
RBC $\left(\mathrm{n} \times 10^{6} / \mathrm{ul}\right)$ & $10.97 \pm 2.21^{*}$ & $9.83 \pm 2.37^{*}$ & $9.58 \pm 3.13^{*}$ & $10.24 \pm 1.07^{*}$ & $9-15$ \\
WBC $(\mathrm{n} / \mathrm{ul})$ & $8369.73 \pm 90.95^{*}$ & $9131.81 \pm 173.23^{*}$ & $12352.74 \pm 257.06 £$ & $8447.36 \pm 320.93^{*}$ & $4000-12000$ \\
Neutrophils $(\mathrm{n} / \mathrm{ul})$ & $4673.19 \pm 113.69^{*}$ & $5787.19 \pm 203.37^{*}$ & $8903.26 \pm 398.21 £$ & $4751.19 \pm 285.65^{*}$ & $2000-9000$ \\
Lymphocytes $(\mathrm{n} / \mathrm{ul})$ & $3874.97 \pm 314.14^{*}$ & $411.07 \pm 185.91^{*}$ & $5341.83 \pm 129.46 £$ & $3963.22 \pm 211.39^{*}$ & $2000-9000$ \\
Monocytes $(\mathrm{n} / \mathrm{ul})$ & $150.27 \pm 56.23^{*}$ & $164.53 \pm 77.16^{*}$ & $172.03 \pm 51.21^{*}$ & $159.27 \pm 49.14^{*}$ & $0-750$ \\
Eosinophils $(\mathrm{n} / \mathrm{ul})$ & $287.39 \pm 63.85^{*}$ & $313.56 \pm 42.37^{*}$ & $295.93 \pm 66.09^{*}$ & $308.02 \pm 73.26^{*}$ & $0-1000$ \\
Basophils $(\mathrm{n} / \mathrm{ul})$ & $81.08 \pm 13.37^{*}$ & $99.34 \pm 27.03^{*}$ & $89.37 \pm 67.28^{*}$ & $93.25 \pm 39.89^{*}$ & $0-300$ \\
Plasma protein $(\mathrm{g} / \mathrm{dl})$ & $6.56 \pm 1.05^{*}$ & $7.41 \pm 1.87^{*}$ & $9.12 \pm 2.57 £$ & $6.91 \pm 0.72^{*}$ & $6.0-7.5$ \\
Plasma fibrinogen $(\mathrm{mg} / \mathrm{dl})$ & $356.44 \pm 31.27^{*}$ & $404.27 \pm 50.35^{*}$ & $503.57 \pm 89.61 £$ & $388.51 \pm 10.18^{*}$ & $100-500$ \\
\hline
\end{tabular}

Presence of different characters $(*, £)$ shows significant differences $(\mathrm{P} \leq 0.05)$ between groups in every row.

Table 3: Biochemical parameters and their reference values according to Oregon State University (2018)

\begin{tabular}{lccccc}
\hline Parameters & $\begin{array}{c}\text { Initial } \\
\text { measurement }\end{array}$ & $\begin{array}{c}\text { Treatment } 1 \\
\text { (Grain }+ \\
\text { Gundelia } \text { Hay) }\end{array}$ & $\begin{array}{c}\text { Treatment } 2 \\
\text { Gundelia } \text { Hay) }\end{array}$ & $\begin{array}{c}\text { Control Group } \\
\text { (Grain + Alfalfa } \\
\text { Hay) }\end{array}$ & $\begin{array}{c}\text { Reference } \\
\text { Value* }\end{array}$ \\
\hline Albumin $(\mathrm{g} / \mathrm{dl})$ & $3.29 \pm 1.42^{*}$ & $3.18 \pm 1.13^{*}$ & $2.46 \pm 1.71 £$ & $3.51 \pm 0.81^{*}$ & $2.5-3.9$ \\
BUN $(\mathrm{mg} / \mathrm{dl})$ & $26.32 \pm 2.16^{*}$ & $29.23 \pm 2.34^{*}$ & $19.14 \pm 5.03 £$ & $31.14 \pm 4.25^{*}$ & $10-35$ \\
Cholesterol $(\mathrm{mg} / \mathrm{dl})$ & $40.18 \pm 1.93^{*}$ & $44.37 \pm 2.57^{*}$ & $53.45 \pm 4.19 £$ & $42.79 \pm 3.08^{*}$ & $40-76$ \\
Creatinine $(\mathrm{mg} / \mathrm{dl})$ & $1.49 \pm 0.69^{*}$ & $1.72 \pm 0.65^{*}$ & $1.37 \pm 0.22^{*}$ & $1.61 \pm 0.39^{*}$ & $0.9-2.0$ \\
Glucose $(\mathrm{mg} / \mathrm{dl})$ & $59.38 \pm 10.34^{*}$ & $67.89 \pm 9.01^{*}$ & $48.89 \pm 8.76 £$ & $70.89 \pm 9.34^{*}$ & $50-85$ \\
Lipase $(\mathrm{IU} / \mathrm{L})$ & $25.25 \pm 3.82^{*}$ & $29.83 \pm 4.08^{*}$ & $36.29 \pm 5.47 £$ & $27.31 \pm 2.55^{*}$ & $1-71$ \\
Total Protein $(\mathrm{g} / \mathrm{dl})$ & $6.56 \pm 0.68^{*}$ & $7.45 \pm 2.29^{*}$ & $8.21 \pm 2.73 £$ & $6.93 \pm 1.07^{*}$ & $5.5-7.5$ \\
Calcium $(\mathrm{mg} / \mathrm{dl})$ & $9.94 \pm 1.27^{*}$ & $10.13 \pm 3.01^{*}$ & $9.38 \pm 3.25^{*}$ & $10.77 \pm 2.17^{*}$ & $8.5-12$ \\
Magnesium $(\mathrm{mg} / \mathrm{dl})$ & $2.45 \pm 0.61^{*}$ & $2.631 \pm 0.22^{*}$ & $2.29 \pm 0.83^{*}$ & $2.73 \pm 0.43^{*}$ & $2.2-2.8$ \\
Phosphorus $(\mathrm{mg} / \mathrm{dl})$ & $5.37 \pm 0.83^{*}$ & $5.99 \pm 0.43^{*}$ & $6.82 \pm 1.18^{*}$ & $6.07 \pm 0.39^{*}$ & $5.0-7.5$ \\
Sodium $(\mathrm{mEq} / \mathrm{L})$ & $152.43 \pm 2.95^{*}$ & $150.28 \pm 4.19^{*}$ & $147.53 \pm 2.27^{*}$ & $153.69 \pm 3.51^{*}$ & $145-155$ \\
Potassium $(\mathrm{mEq} / \mathrm{L})$ & $4.71 \pm 0.28^{*}$ & $5.32 \pm 0.56^{*}$ & $4.81 \pm 0.33^{*}$ & $5.24 \pm 0.73^{*}$ & $4.5-6$ \\
Chlorine $(\mathrm{mEq} / \mathrm{L})$ & $101.97 \pm 3.43^{*}$ & $102.63 \pm 3.57^{*}$ & $99.16 \pm 2.78^{*}$ & $105.35 \pm 4.13^{*}$ & $95-112$ \\
\hline
\end{tabular}

Presence of different characters $(*, £)$ shows significant differences $(\mathrm{P} \leq 0.05)$ between groups in every row.

\section{Discussion}

It is possible to judge about efficacy of diets according to the parameters of metabolism in the animal's body. In other words, when a diet is efficient then all of the parameters of metabolisms are in the range of normal values, otherwise diet is not efficient and perfect. The biochemical mechanisms, which the chemical energy 
contained in foodstuffs are made available to the human/animal's body, are collectively described as metabolism. Thus, the description of the metabolism of a foodstuff encompasses the biochemical events that occur from the moment of ingestion to its final breakdown and excretion, and classically, these biochemical events have been divided into the metabolism of the three major constituents of food; carbohydrates, proteins, and lipids (18). In the current study, the effects of diets containing different amount of Gundelia tournefortii L. on performance rate and hematologic and biochemical parameters (efficacy of diets) in Iranian Afshari breed fattened sheep were studied for the first time.

It is identified that the major components of Gundelia are palmitic acid, lauric acid, alpha ionene, myristic acid, 1hexadecanol, 2-methyl, phytol and beta turmerone. Seed oil of this plant has oleic and linoleic acid contents. Gundelia flower buds are rich in crude oil, crude protein, crude fiber, potassium, calcium, phosphorous, sodium, ferric, magnesium and zinc. The oil of flower buds is rich in linoleic, oleic, palmitic, stearic, vacsenic, arachidic acids, etc., also it has great amounts of vitamin $\mathrm{E}$ active compounds as $\alpha$-tocopherol and $\gamma$-tocopherol. Carbohydrates level in this plant is low, so it cannot act as a great direct energy source $(3,13,19)$. The result of current study agreed with mentioned data and shows that concentration of glucose, as the main source for energy in body, has decrease due to feeding of diet containing this plant singly, and decrease of glucose concentration resulted in poor performance rate in this group's animals, but this decrease can be solved by combination of Gundelia hay with other materials like grains, and in the current study, animals which were fed oat grain and Gundelia hay had great performance rate.

As mentioned in last paragraph, Gundelia has so many lipid/fat components which need processing to be accessed in body. Lipase is an enzyme that catalyzes the hydrolysis of fats/lipids and has essential roles in the digestion, transport and processing of dietary lipids $(20,21)$. Also, cholesterol is a type of lipid molecules biosynthesized by all animal cells. It is an essential structural component of all animal cell membranes and is essential to maintain both membrane structural integrity and fluidity. Cholesterol allows animal cells to function without a cell wall; in addition, it serves as a precursor for the biosynthesis of steroid hormones, bile acid and etc. (22). The result of the current study shows that serum concentration of cholesterol and lipase as a parameter of lipid synthesis had an increasing in groups which were fed diets containing different amounts of Gundelia tournefortii L., and it is clear that Gundelia can act as a great source of fatty acids for animals.

Blood urea nitrogen (BUN) shows the amount of urea nitrogen found in blood. The liver produces urea in the urea cycle as a waste product of the digestion of protein. BUN concentration may be useful indicator of protein status within a group of animals, and could help to fine-tune diets or identify problems with a feeding program $(23,24)$. The result of this study shows that BUN had a decrease in groups that were fed Gundelia. It is identified that the level of proteins in this plant is low (13), so production of urea as a waste metabolite of protein's digestion will be lesser due to diets containing it singly, but this lower amount of proteins can be solved by combination of Gundelia with other sources having higher amount of proteins like grains and alfalfa hay.

White blood cells or leukocytes are important part of the immune system and are involved in protection of body. Their numbers will be increased due to any infectious diseases (25). The results of the present study show that total number of White Blood Cells (WBC), differential number of neutrophils and differential number of lymphocytes had an increasing in groups fed diet containing Gundelia. It was unidentified since all the animals were health and without any signs of diseases, so astute clinical examinations were done; oral lesions due to insertion of plant's acicula were reason. These lesions were lesser in group fed by diet containing oat grain and Gundelia, so in this group the increase of the abovementioned parameters was not significant. Also, fibrinogen is a glycoprotein that in animals circulates in the blood. During tissue and vascular injury, it is converted enzymatically by thrombin to fibrin and subsequently to a fibrin-based blood clot. Fibrinogen functions primarily to occlude blood vessels and thereby stop excessive bleeding. However, fibrinogen's product (fibrin) binds and reduces the activity of thrombin. Fibrinogen production is stimulated due to any damage which can make bleeding in the body $(26,27)$. In the current study increase in concentration of plasma fibrinogen was a subsequent result of inflammation reactions due to oral lesions and parallel increases in both of plasma and serum protein concentration, at the same time with increase in fibrinogen concentration in plasma and decreasing of albumin concentration in serum, indicate that they were obviously as subsequent results of inflammation reactions due to oral lesions. In order to reduce these predictable lesions, it is traditionally suggested to moisten hay before use.

In conclusion, the current study as the first one shows the effects of diets containing Gundelia tournefortii L. on performance rate and health status of animals. Performance rate of treatment 2, which was fed Gundelia hay singly, was lower than other groups and performance rates of combined diets of grain and Gundelia and diet of grain and alfalfa hay were similar and also efficient. The total number of White Blood Cells (WBC), differential number of neutrophils and lymphocytes, concentration of plasma proteins, concentration of plasma fibrinogen and serum 
concentration of total protein, cholesterol and lipase had increases in treatment groups, which were fed Gundelia, but serum concentration of glucose, albumin and Blood Urea Nitrogen (BUN) had a decrease in in these groups versus control group. Briefly, given to low costs and highperformance rate, which may be related to presence of high amount of fatty acids in diet containing Gundelia and grains, this diet can be considered as a good source of food in fattened sheep, but Gundelia-based diet, which has it singly, is not efficient in fattened sheep. Study on meat quality, like meat's fat level, in animals due to receiving of diet containing Gundelia is suggested as a subject for the next studies.

\section{Conflict of interest}

Authors certify there are no financial and personal relationships with other people or organizations which can influence or bias their work and declare that there is no any conflict of interest.

\section{Acknowledgments}

Authors are grateful to Dr. Azam Dehghani-Samani (Financial support of study), Mr. Ayat Dehghani-Samani (Owner of farm and animals) and all of the persons who helped them to do this research.

\section{References}

1. Mohammadi AR, Abbasi MA, Moghaddam AA, Shahneh AZ. Determination of some reproductive traits in Iranian Afshari sheep breed. Aust J Basic Applied Sci. 2011;5(12):2742-2751.

2. Mohammadi AR, Abbasi MA, Moghaddam AA, Shahneh AZ. Estimation of growth traits in Iranian Afshari sheep breed under rural production system. J Anim Vet Adv. 2009;8(7):1449-1454.

3. Farhang HR, Vahabi MR, Allafchian AR. Chemical compositions of the essential oil of Gundelia tournefortii L. (Asteraceae) from Central Zagros, Iran. J Herbal Drugs. 2016;6(4):227-233.

4. Lev-Yadun S, Abbo S. Traditional use of A'kub (Gundelia tournefortii, Asteraceae), in Israel and the Palestinian Authority Area. Econ Bot. 1999;53(2):217-219.

5. Ertug F. An ethnobotanical study in central Anatolia (Turkey). Econ Bot. 2000;54(2):155-182.

6. Dogan Y, Baslar S, Ay G, Mert HH. The use of wild edible plants in western and central Anatolia (Turkey). Econ Bot. 2004;58(4):684-690.

7. Jamshidzadeh A, Fereidooni F, Salehi Z, Niknahad H. Hepatoprotective activity of Gundelia tourenfortii. J Ethnopharmacol. 2005;101(1-3):233-237.

8. Haghi G, Hatami A, Arshi R. Distribution of caffeic acid derivatives in Gundelia tournefortii L. Food Chemist. 2011;124(3):1029-1035.
9. Sezik E, Yeșilada E, Honda G, Takaishi Y, Takeda Y, Tanaka T. Traditional medicine in Turkey X. Folk medicine in central Anatolia. J Ethnopharmacol. 2001;75(2-3):95-115.

10. Halabi S, Battah AA, Aburjai T, Hudaib M. Phytochemical and antiplatelet investigation of Gundelia tournifortii. Pharmaceutic Biol. 2005;43(6):496-500.

11. Jarald E, Joshi SB, Jain DC. Diabetes vs herbal medicines. Iranian J Pharm Therapeut. 2008;7(1):97-105.

12. Sarper F, Akaydin G, Şimşek I, Yeşilada E. An ethnobotanical field survey in the Haymana district of Ankara province in Turkey. Turkish J Biol. 2009;33(1):79-88.

13. Matthäus B, Özcan MM. Chemical evaluation of flower bud and oils of tumbleweed (Gundelia tourneforti L.) as a new potential nutrition source. J Food Biochemist. 2011;35(4):1257-1266.

14. Smith MH. Sheep Nutrition, What You Need to Know. ANR Publication 8476, University of California, California, USA; 2014.

15. Weiser G. Laboratory technology for veterinary medicine. In: Thrall MA, Weiser G, Allison R, Campbell T, editors. Veterinary hematology and clinical chemistry, $2^{\text {nd }}$ ed. Hoboken, New Jersey: John Wiley and Sons; 2012. p. 20-33.

16. Oregon State University: Hematology Reference Interval [Internet]. Veterinary Diagnostic Laboratory, College of Veterinary Medicine, Oregon State University, Corvallis, Oregon, USA; 2018.

17. Oregon State University: Biochemistry Reference Interval [Internet]. Veterinary Diagnostic Laboratory, College of Veterinary Medicine, Oregon State University, Corvallis, Oregon, USA; 2018.

18. Jerry Kaneko J. Carbohydrate metabolism and its diseases. In: Kaneko JJ, Harvey JW, Bruss M, editors. Clinical biochemistry of domestic animals, $6^{\text {th }}$ ed. Oxford, United Kingdom: Gulf Professional Publishing; 2008. p. 45-80.

19. Khanzadeh F, Haddad Khodaparast MH, Elhami Rad AH, Rahmani F. Physiochemical properties of Gundelia tournefortii L. seed oil. J Agri Sci Technol. 2012;14:1535-1542.

20. Svendsen A. Lipase protein engineering. Biochimica et Biophysica Acta. 2000;1543(2):223-228

21. Girod A, Wobus CE, Zádori Z, Ried M, Leike K, Tijssen P, Kleinschmidt JA, Hallek M. The VP1 capsid protein of adenoassociated virus type 2 is carrying a phospholipase A2 domain required for virus infectivity. J Gen Virol. 2002;83(5):973-978.

22. Hanukoglu I. Steroidogenic enzymes: structure, function, and role in regulation of steroid hormone biosynthesis. J Steroid Biochem Mol Biol. 1992;43(8):779-804.

23. Kohn RA, Kalscheur KF, Russek-Cohen E. Evaluation of models to estimate urinary nitrogen and expected milk urea nitrogen1. J Dairy Sci. 2002;85(1):227-233.

24. Kohn RA, Dinneen MM, Russek CE. Using blood urea nitrogen to predict nitrogen excretion and efficiency of nitrogen utilization in cattle, sheep, goats, horses, pigs, and rats1. J Anim Sci. 2005;83(4):879-889.

25. Weiser G. Introduction to leukocytes and the leukogram. In: Thrall MA, Weiser G, Allison R, Campbell T, editors. Veterinary hematology and clinical chemistry, $2^{\text {nd }}$ ed. New Jersey: John Wiley and Sons; 2012. p. 118-122.

26. Everse SJ, Spraggon G, Veerapandian L, Riley M, Doolittle RF. Crystal structure of fragment double-D from human fibrin with two different bound ligands. Biochemistry. 1998;37(24):8637-8642.

27. Mosesson MW. Fibrinogen and fibrin structure and functions. J Thrombosis Haemostasis. 2005;3(8):1894-1904. 